\title{
OPEN Publisher Correction: Size increase without genetic divergence in the Eurasian water shrew Neomys fodiens
}

\author{
Alfonso Balmori-de la Puente, Carlos Nores, Jacinto Román, Angel Fernández-González, \\ Pere Aymerich, Joaquim Gosálbez, Lídia Escoda \& Jose Castresana(i)
}

Correction to: Scientific Reports https://doi.org/10.1038/s41598-019-53891-y, published online 22 November 2019

Two supplementary files, Appendix S1 and Appendix S2, were omitted from the original version of this Article. This has been corrected in the HTML version of this article; the PDF version was correct at time of publication.

(c) (i) Open Access This article is licensed under a Creative Commons Attribution 4.0 International cc) License, which permits use, sharing, adaptation, distribution and reproduction in any medium or format, as long as you give appropriate credit to the original author(s) and the source, provide a link to the Creative Commons license, and indicate if changes were made. The images or other third party material in this article are included in the article's Creative Commons license, unless indicated otherwise in a credit line to the material. If material is not included in the article's Creative Commons license and your intended use is not permitted by statutory regulation or exceeds the permitted use, you will need to obtain permission directly from the copyright holder. To view a copy of this license, visit http://creativecommons.org/licenses/by/4.0/.

(C) The Author(s) 2020 